\title{
Finishing strategies for Belgian Blue and Limousin cross steers
}

M G Keane

Teagasc, Dunsany, Co. Meath, Ireland

Email: gerry.keane@teagasc.ie

Introduction Belgian Blue and Limousin sires are used for cross breeding with Holstein-Friesian dairy cows and the resultant male calves are used for beef production. In beef winter finishing enterprises, a preliminary period of variable feeding may precede the finishing period to postpone slaughter date until beef prices are higher in late spring. The optimum feeding level in such a preliminary period has not been established. The aim of this study was to determine the effects of three feeding levels during a preliminary finishing period on feed intake, growth and carcass traits of Belgian Blue $x$ Holstein-Friesian (BB) and Limousin x Holstein-Friesian (LM) steers.

Materials and methods Forty eight steers (24 BB and 24 LM) were blocked on live weight (BB 368, LM 391, s.d. 11.3, $\mathrm{kg}$ ) within breed and assigned to 3 feeding levels for a preliminary feeding period of 112 days followed by finishing on concentrates ad libitum to a target slaughter weight of $610 \mathrm{~kg}$. The 3 feeding levels in the preliminary period were (i) grass silage only (S0), (ii) S0 + $2.57 \mathrm{~kg}$ concentrate dry matter (DM) per head daily (S3), (iii) S0 + 5.13 kg concentrate DM per head daily. The silage analysis was $208 \mathrm{~g} / \mathrm{kg} \mathrm{DM}, 146 \mathrm{~g} / \mathrm{kg}$ crude protein in DM, $701 \mathrm{~g} / \mathrm{kg}$ in vitro DM digestibility, $\mathrm{pH}$ 3.9. The concentrate formulation was $875 \mathrm{~g} / \mathrm{kg}$ rolled barley, $65 \mathrm{~g} / \mathrm{kg}$ soya bean meal, $45 \mathrm{~g} / \mathrm{kg}$ molasses and $15 \mathrm{~g} / \mathrm{kg}$ mineral/vitamin premix. Accommodation was a slatted shed fitted with Calan boxes for individual feed recording. The animals were slaughtered in a commercial abattoir where cold carcass weight ( 0.98 hot weight), carcass grades for conformation and fatness, and weights of perirenal plus retroperitoneal fat were recorded. The data were statistically analysed as a 2 (breeds) x 3 (feeding levels) factorial, using general linear model least squares procedures, with terms for block, breed, feeding level and breed $\mathrm{x}$ feeding level.

Results As a consequence of their heavier initial live weight, LM were still heavier $(\mathrm{P}<0.001)$ than $\mathrm{BB}$ after 112 days, but at slaughter there was no difference in live weight between the breeds. BB tended to have higher daily live weight gains than LM during finishing but the differences were not significant. BB had a higher $(\mathrm{P}<0.001)$ kill-out and a lower $(\mathrm{P}<0.001)$ carcass fat class than LM. At the end of the preliminary period, S3 was $53 \mathrm{~kg}$ heavier $(\mathrm{P}<0.05)$ than $\mathrm{S} 0$, and $\mathrm{S} 6$ was $26 \mathrm{~kg}$ heavier $(\mathrm{P}<0.05)$ than $\mathrm{S} 3$. After 97 days on ad libitum concentrates (day 209), S3 had overtaken S6 in live weight, and the difference between S0 and S3 was reduced to $34 \mathrm{~kg}(\mathrm{P}<0.05)$. Both S3 and S6 reached slaughter weight at the same time while S0 required a further 35 days to slaughter weight. During the preliminary period, daily live weight gain responses to the first and second $2.57 \mathrm{~kg}$ /day concentrate DM increments were 483 and 220 g, respectively. The corresponding differences in the opposite direction afterwards to 209 days were 189 and $300 \mathrm{~g}$. Other than carcass fat class which was higher for S0 there were no differences in carcass traits. For similar slaughter and carcass weights, S6 required more $(\mathrm{P}<0.001)$ concentrates and net energy than both $\mathrm{S} 0$ and $\mathrm{S} 3$, while $\mathrm{S} 0$ required more $(\mathrm{P}<0.001)$ silage and net energy than S3.

Conclusions $\mathrm{BB}$ had superior finishing traits to LM with a higher kill-out proportion, better carcass conformation and a lower carcass fat class. S3 achieved similar slaughter and carcass weights to S6 with $357 \mathrm{~kg}$ less concentrate DM (but 154 $\mathrm{kg}$ more silage DM) and 290 UFV less net energy. S0 and S3 had similar concentrate intakes but S0 required $163 \mathrm{~kg}$ more silage DM and 148 UFV more net energy. Where a preliminary feeding period precedes a finishing period on ad libitum concentrates, the target growth rate during that period should be around $0.8 \mathrm{~kg} / \mathrm{day}$. Higher growth rates will be compensated during finishing while lower growth rates require an extended finishing period.

Table 1 Effects of breed and finishing strategy on steer performance

\begin{tabular}{|c|c|c|c|c|c|c|c|c|c|}
\hline & \multicolumn{2}{|c|}{ Breed (B) } & \multicolumn{3}{|c|}{ Finishing Strategy $(\mathrm{F})$} & \multirow[t]{2}{*}{ s.e $e^{1}$} & \multicolumn{3}{|c|}{ Significance } \\
\hline & $\mathrm{BB}$ & LM & S0 & S3 & S6 & & $\mathrm{B}$ & $\mathrm{F}$ & $\mathrm{BxF}$ \\
\hline LW at 112 days (kg) & 463 & 481 & $428^{a}$ & $481^{\mathrm{a}}$ & $507^{\mathrm{c}}$ & 3.5 & $* * *$ & $* * *$ & NS \\
\hline LW at slaughter (kg) & 609 & 618 & 615 & 614 & 611 & 6.7 & NS & NS & NS \\
\hline ADG $0-112$ days $(\mathrm{g})$ & 848 & 805 & $431^{\mathrm{a}}$ & $914^{\mathrm{b}}$ & $1134^{\mathrm{c}}$ & 26.0 & NS & $* * *$ & $*^{4}$ \\
\hline ADG $112-209$ days $^{2}(\mathrm{~g})$ & 1365 & 1310 & $1563^{\mathrm{a}}$ & $1374^{\mathrm{b}}$ & $1074^{\mathrm{c}}$ & 57.3 & NS & $* * *$ & NS \\
\hline ADG 0 days-slaughter (g) & 1076 & 1009 & $945^{\mathrm{a}}$ & $1101^{\mathrm{b}}$ & $1081^{\mathrm{b}}$ & 29.5 & NS & $* *$ & NS \\
\hline Days to slaughter & 226 & 226 & 249 & 214 & 214 & - & - & - & - \\
\hline Carcass weight $(\mathrm{kg})$ & 338 & 339 & 333 & 334 & 334 & 4.0 & NS & NS & NS \\
\hline Kill-out $(\mathrm{g} / \mathrm{kg})$ & 556 & 533 & 542 & 545 & 547 & 2.8 & $* * *$ & NS & NS \\
\hline Fat class & 3.1 & 3.8 & $3.6^{\mathrm{a}}$ & $3.4^{\mathrm{b}}$ & $3.4^{\mathrm{b}}$ & 0.05 & $* *$ & $*$ & $* * * 5$ \\
\hline Total silage intake $(\mathrm{kg})^{3}$ & 820 & 830 & $985^{\mathrm{a}}$ & $822^{b}$ & $668^{c}$ & 16.6 & NS & $* * *$ & NS \\
\hline Total concentrate intake $(\mathrm{kg})^{3}$ & 1469 & 1476 & $1369^{\mathrm{a}}$ & $1345^{\mathrm{b}}$ & $1702^{b}$ & 9.0 & NS & $* * *$ & NS \\
\hline Total net energy intake (UFV) ${ }^{4}$ & 2267 & 2282 & $2276^{\mathrm{a}}$ & $2128^{\mathrm{b}}$ & $2418^{\mathrm{c}}$ & 21.8 & NS & $* * *$ & NS \\
\hline
\end{tabular}

${ }^{1}$ For Breed; ${ }^{2}$ Last common weight before slaughter; ${ }^{3} \mathrm{DM} ;{ }^{4}$ Unite Fourragere Viande; ${ }^{4}$ Values for S0, S3 and S6 = 401, 901 and $1234(\mathrm{BB})$, and 453, 927 and 1035 (LM); ${ }^{5}$ Values for S0, S3 and S6 = 3.0, 3.0 and $3.3(\mathrm{BB})$, and 4.2, 3.7 and 3.6 (LM);

${ }^{\mathrm{abc}}$ Values with a

common superscript do not differ significantly $(\mathrm{P}>0.05)$; $\mathrm{LW}=$ live weight; $\mathrm{ADG}=$ average daily gain. 